\title{
Impacts of Illegal Urbanization on Fire Crash Hazards: A Case Study of Dhaka, Bangladesh
}

Md Saiful Islam ( $\nabla$ saifulislam.jupa@gmail.com )

Selçuk University: Selcuk Universitesi https://orcid.org/0000-0002-2149-0075

Ali ŞAHIN

Selçuk Üniversitesi: Selcuk Universitesi

\section{Research Article}

Keywords: Hazard, Fire Crash Hazard, Urbanization, Illegal Urbanization, Dhaka

Posted Date: February 15th, 2022

DOI: https://doi.org/10.21203/rs.3.rs-1329443/v1

License: (c) (1) This work is licensed under a Creative Commons Attribution 4.0 International License. Read Full License 


\section{Abstract}

The study discusses the illegal urbanization and unfortunate fire crash hazards in different parts of Dhaka city. The security and safety of the city's people and their entire economy's wheel will inevitably come to a halt, even when the crisis remains the same in a particular phase. Thus, Dhaka city's infrastructure, as well as the country's economy, will be threatened. The quantitative method was adopted, and data was collected via an online questionnaire survey and existing published sources, official records, and survey reports. The Ordinal Logistic Regression (OLR) analysis revealed fire crash hazards in Dhaka due to illegal urbanization. Some disappointing factors of urbanization have been identified that are responsible for fire crash hazards in Dhaka city. The study results also detect that fire crash hazards have a high economic effect. For this reason, policymakers, city planners, and politicians need to search for solutions to these fire crash hazards. Requiring sustainable directions and urban progress of Dhaka city, the study outcomes come up with several relatable strategy policies and initiatives embedded at the end of the research.

\section{Introduction}

Urbanization happens from rural to urban migration inside countries or foreign migrants congregating in global cities. Moreover, this demographic force has been a critical driver of urbanization (Westfall \& Villa, 2001). Moreover, over 50 percent of the globe's population currently resides in urban centers (from 30 percent in 1950 to 55 percent in 2018). The urban population worldwide is estimated to reach 2.5 billion residents, with Asia and Africa accounting for approximately 90 \% of the rise (United Nations, Department of Economic and Social Affairs, Population Division, 2019). For eample, Bangladesh's urban population rose from 6.27 million in 1974 to over 39 million in 2011. Over time, the rate of urbanization (the proportion of the populace residing in urban areas) has increased from 8.78-27.66\%. From now on, population growth in Bangladesh is projected to be primarily urban, with urban zones expected to house $50 \%$ of the country's population by 2047 (Islam N., 2018).

Dhaka has been adjudged as one of the dirtiest cities globally, known as the highly crowded, features high crime, tight traffic zone, slum areas, unplanned risky buildings, and making its citizens fear their safety. Nevertheless, it has a very populous and rich history for its beauties and standards. The settlements and location of the earlier Dhaka city were very strategic because of its accessibility, water communication trading routes, and building structure. Dhaka is situated on the Buriganga River's bank. Before the 1980s, the city was predominantly spontaneous and organic. Then a few planned residential neighborhoods developed. Rapid urbanization, ecological pollution, stealing lands, poor governance, corrupt practices, and ideological conflict are examples of how the city communicates its experiences in its current form. With 18.2 million people living in 1528 square kilometers, Dhaka, Bangladesh's capital, is the world's eleventh largest mega-city city (Swapan \& U., 2017). "Mega-city" belongs to a rapidly evolving urban process with more than 10 million residents. (Pelling \& Blackburn, 2013). Dhaka mega-city is one of the dirtiest cities and densely populated cities globally, with a population size of 11,910 individuals for every square kilometer. By 2025, Dhaka's ongoing population is projected to grow around 22 million, with a 4.4 percent growth rate annually (RAJUK, 2015).

In the urban context, the increasing frequency of natural hazards due to changing climate has a high level of risk to people in the city. Directly or indirectly, climate change keeps these natural hazards (including floods, earthquakes, and fires) rising. Fire is a vulnerability (The Geneva Association, 2014), and fire crash hazard is one of these occurrences currently inflicting massive economic loss and the tragedy of human mortality regularly. In recent years, fire crash hazard has become a burning issue (Venkatesh, Puneet, \& Muhammad Masood, 2020). From 1993 to 2015, with more than one million deaths, a total of 86.4 million fire incidents have happened in the world (Nikolai, Marty, Sergei, \& Peter, 2017). Based on the Bangladesh Fire Service and Civil Defence data about TK. 330,41,28,774 loss with 24,074 fire incidents were happened. And 21,073 fire accidents with about TK. 246,65,95044 lost in 2020 (BFSCDA, 2020). In the context of Dhaka city, the rapid unplanned urbanization processes a dualistic nature of opportunities and challenges. It promises a decent living atmosphere because it is a place of residence for millions of people and desires even more lives. This financially viable mega-city has the potential to contribute to this impoverished country to a prosperous future. Compared to other Bangladeshi cities, Dhaka City has the highest yearly death and monetary loss due to fire incidents. According to the official record of BFSCDA, in 2019, 125 people died only in Dhaka divisions, where 184 people died in the rest of seven divisions, and it was 47 in Dhaka, and the rest of divisions were 130 deaths. The monetary loss due to fire accidents within Dhaka City was Tk.21,520,000 in 2018, Tk.892,964,000 in 2019 (BFSCDA, 2019). Dhaka is not given much attention in terms of city planning due to illegal urbanization. The current study explores the rapid unplanned urbanization in Dhaka city with fire crash hazards. It provides a comprehensive review of works concerning informal urbanization and outlines a meaningful solution for fire crash hazards. People lose their parents, children, and relatives in Dhaka city and become homeless every year due to fire crash hazards. So, this is a crying need to find out the culprits responsible for fire crash hazards. Also, the study suggests some policy initiatives against rapid unplanned urbanization to protect people from fire crash hazards. It is not only for Dhaka city, but it will be useful for many cities in this globe facing illegal urbanization.

\section{Urbanization And Dhaka City}

Mega-cities cannot accept new migrants due to the tremendous urban transition from remote parts of the country, whether for earning money or because of natural catastrophes. Subsequently, the urban underprivileged people understood that they could find interim shelter in slum areas and squat houses built on state property. With the booming populace, an off-the-cuff financial system in the form of street-based self-employment, home-based jobs, and building project workforce hires a considerable portion of the population in mega-cities alongside professional career fields (Daniels, 2004).

'Urbanization' is a very familiar concept of the 21 st century. Before the 19th century, this concept was hardly used both in the dictionary and practical areas. 'Urbanization' is derived from the Latin' urbs' - a term applied by the Romans to a city - more especially the 'City of Rome' (Notridge, 2007). The growth of town life is related to the quickening of the tempo of civilization. Then it was found in the civilization of Egypt, India, Mesopotamia, Greece, Rome, or Byzantium. Urbanization in its minimal meaning is the study of the growth of cities. It is, more particularly, the study of the process of population 
concentration within human settlements (the city), as well as the expansion of cities into surrounding communities (suburbanization) and regions (Hutchison, 2010).

\section{Table 1: Different Definitions of Urbanization by Chosen Countries.}

Besides, urbanization is a complicated economic and social procedure that alters urban development, converting remote communities into urbanized areas and shifting the population's regional allocation from the countryside to the cities. It also modifies the significant professions, lifestyles, cultures, and behaviors and influences urban and rural areas' demographic and social structures (Montgomery, Stren, Cohen, \& Reed, 2003). The main effect of urbanization is an increase in the total amount, dimensions, and demography of urbanized areas and an increase in urban inhabitants compared to rural people. In reality, the term "urbanization" indicates an increase in the proportion of lives of people living in urban settlements, as well as a surge in the volume of city dwellers, the length of urban centers, as well as the overall land owned by urbanized areas (United Nations, Department of Economic and Social Affairs, Population Division, 2019).

However, the definition of 'urbanization' varies from country to country as well as it is a very up-to-date concept. Because after each census, administrative area, population size, local government area, urban characteristics, and economic activity also must be updated and sometimes dramatically changed. Like the above way, it may be defined by different organizations, groups, urban specialists, and academicians. However, it might be tough to define as an absolute term. As a result, Table 1 shows how various nations represent urbanization. These are very formal and updated in terms of urban characteristics from time to time. Formal urbanization is related to the process in which rules and regulations follow migrants and settlements. In the literature, the term "informal urbanization" was coined to describe the expansion of informal settlements populated by the urban poor (Hossain, 2012; Hackenbroch, Hossain, Altrock, Schoon, \& Sterly, 2016).

Since 2001, the Government of Bangladesh has defined 'urbanization' as termed in 1981. However, in 2011, the Statistical Metropolitan Area (SMA) changed the definition of urbanization. The areas covered only city corporations, paurashavas, Upazila headquarters, and cantonment areas. Bangladesh Bureau of Statistics (BBS) reports that 'Urbanization of Bangladesh has changed into six urban areas and also updated their functions and sizes' (BBS, 2014).

Mega-city- having populations of about 5 million or more (Metropolitan area).

City Corporation- incorporated and administered by the Ministry of Local Government under City Corporation Act, 2009.

Paurashava/Municipality Area (PSA) - incorporated and administered by the local government under Paurashava Ordinance, 1977.

City- having a population of about 100,000 and above (urban area).

Other Urban Area (OUA) - Upazila headquarters (not included in Paurashava) and Unions (based on urban characteristics, such as 17 unions adjacent to Dhaka City Corporation under Dhaka Metropolitan Area) are the Other Urban Area (OUA).

Town- (urban area) having population less than 100,000 (BBS, 2014; RAJUK, 2015).

The style and form of urbanization in Bangladesh, on the other hand, are not always comparable to those in other nations. Because it has a long history as a rural-agrarian country is rapidly transforming into an urban society. In Bangladesh, the urban population has increased rapidly during the last couple of decades (see figure 1). Between 2000 and 2010, Bangladesh witnessed quicker urbanization than the rest of South Asia. In $2010,21.3$ percent of Bangladesh's urban population lived in poverty, while over 62 percent lived in slums in 2009. Poverty and slums result from illegal urbanization (World Bank, 2015). Dhaka has indeed been witnessing rapid urban growth due to extensive population pressure. Of course, migration has been the most critical factor in urban population increase. This percentage might be much higher in big cities like Dhaka, reaching up to 60\% among household heads (Islam N., 2018). As a result, Dhaka was placed 139th out of 140 cities in the Economist Intelligence Unit's 2015 livability index, ahead of only Damascus. With a score of 110 , Delhi was the highest-ranked of the six South Asian cities, followed by Mumbai (115), Kathmandu (125), Colombo (127), Karachi (135), and Dhaka (World Bank, 2015).

Figure 1: The Growth of Urban Population in Bangladesh.

Nowadays, skyscrapers are being built in each part of Dhaka without proper planning rules and regulations. Because this process does not obey the laws of the existent area, the system of governance is thoroughly corrupted, other peoples or states influence the governing people of that area, migrants come illegally, and settlements are constructed not follow the country's rules and regulations. Dhaka city frequently faces natural hazards (like an earthquake) and man-made hazards (like fire and sound pollution) with this rapid unplanned urbanization. Nowadays, Dhaka City has been experiencing many fire crashes. Dhaka is the only 'Mega-city' composed of many high-rise buildings and slums, and industries. As a result, Dhaka city dwellers have faced urban vulnerabilities and hazards due to rapid building construction and non-conformation of the Fire protection Act, 2003 (Islam \& Adri, 2008). Physical, social, and economic vulnerabilities characterize the urban context of Dhaka, and notably, the slum areas. These urban issues of Dhaka city are firmly connected and increase the risk of potential dangers responsible for urban vulnerabilities and hazards.

\section{Fire Crash Hazards And Dhaka City}

Fire crash hazards happen on buildings in most cities and cause partial or complete collapse, serious injuries or deaths, and tangible and intangible economic damages. As a result, fire crash hazard refers to the possibility of an accidental or on-purpose fire jeopardizing living creatures, security, and assets (Venkatesh, Puneet, \& Muhammad Masood, 2020). For example, in 1906, after a devasting earthquake, a three-day-long fire burned 25,000 buildings, 
died 3000 lives, and migrated 200,000 residents from the San Francisco city (U.S. Geological Survey). The fire crash hazards lose about one percent of world GDP annually (The Geneva Association, 2014), and on average, about 3.8 million fire incidents (Nikolai, Marty, Sergei, \& Peter, 2017). Fire crash hazards impact properties, lives (Tanjiba Rahman \& Ishrat, 2019), and the environment (David \& Kristen, 2021).

From Bangladesh's urban areas perspective, fire is a common incident and creates severe damages every year, including loss of lives and properties. Also, past fireplace events have shown that slum areas have always been the most highly susceptible to fireplace threats in the urban setting (Huq, 1999). According to Syeda Rizwana H (Chief Executive of Bangladesh Environment Lawyers Association-BELA), "In the last ten years, there have been at least 16,000 accidents around the country, killing 1,590 people" (Dhaka Tribune, 2019). The following figure explores information (see Figure 2). While preventing initiatives have not been increased, people are pushed into slum areas with hazardous living and working conditions, revealing higher risks of fire crash hazards due to Bangladesh's rapid and unplanned urbanization. In this context, many places (e.g., Dhalpur City Palli and Balurmath) have been marked by significant fire incidents. Poor living standards due to fire crash hazards of these areas have already adversely affected those who live there.

According to the BFSCDA (Bangladesh Fire Service and Civil Defense Authority), in 2019, "a total of 39 buildings in Dhaka, Gazipur, Savar, and Narayanganj, which are serious fire hazards". Rather than having natural causes, urban fires area units typically anthropogenic evolution activity. For instance, gas cookers are the consequences of fire pit cases at home. On the other hand, in urban slums, the primary factor of fires is from industrial units (DIPECHO, 2010). In this perspective, on June 3, 2010, the horrific Nimtoli fire, which killed 124 people - 11 from the same family and a minimum of 150 more people were injured who were severely burned (Dhaka Tribune, 2019). In slums areas, an illegal chemical storehouse (an associate in the nursing) on the ground floor of the dwelling unit was the primary source of the fireplace.

\section{Figure 2: Deaths and Injured People due to the Fire Crash Hazards in Bangladesh (2006-2020).}

Malfunctioning hazardous chemical substances by mixing industrial and residential housing areas puts inhabitants at severe risks. For example, about 80 percent of unpermitted industries and storehouses can be found in the residential buildings of Old Dhaka (Imam, 2010). Moreover, the lack of state intervention on all these segments increases the underlying fire crash hazards. Furthermore, because they are affected by a short-staffed investigation department, politicians owning stock have a conflict of interest (Watch, 2013). As a result, the politics and economics of Dhaka city lead to enhanced uncertainties, massive damage, and more significant challenges for mitigating the impact of long-term urban fire crash hazards. Also, a lack of fire-response measures and overpopulation in urban slums worsen the losses of fire crash incidents. The following table shows a clear view of fire crash hazards and losses in Dhaka city from 2014 to 2018 (Table 2) respectively. Because fires spread quickly across urban slums due to the dense adjustment of tents and houses, high-density resident peoples make rescue operations nearly impossible. As a result, the average length of fire hazards in the slum areas is noticeably more significant than in non-slum urban settlements. For example, the average time of a fire in the slums of Dhaka city is 68 minutes, compared to 28 minutes in non-slum populated regions (Maniruzzaman K.M., 2013).

\section{Table 2: Estimation of Fire Crash Hazards in Dhaka City.}

On the other hand, according to firefighters, the late response to slum fires is due to minor roads, limited water sources, and scarcity of hydrants that take a long time to put out the flame (CBSNews, 2010). For instance, analysis among Moinanbagh slums in Dhaka city confirmed that conditions area unit too incommodious to permit access to fireplace vehicles. However, the fire hazards in Dhaka city are persistent, and the lives and monetary losses are increasing in every new fire incident. Hence, fire crash hazards are pretty much uncontrollable without measuring the damages of infrastructure and challenges of Dhaka city's inherently social, political, and economic and following rules and regulations of urbanization.

\section{Methodology}

\section{Study Area}

A mega-city Dhaka (Pelling \& Blackburn, 2013), with more than 18.2 million people living in 1528 square kilometers (Swapan \& U., 2017), is the area of this study. Predominantly areas comprise industries, slum areas, chemical and unprocessed leather warehouses where fire incidents are ubiquitous.

\section{Sampling and Data Collection}

An online questionnaire survey was conducted to investigate the matter of urbanization and fire crash hazards in Dhaka city from June 2018 to August 2013. The online questionnaire survey was chosen because of no funding for this research and ease of access for participants. A sample of 150 people has been selected by stratified sampling procedure for this study. Since 2010, all respondents have been living in Dhaka city, many of them from birth.

Secondary data were obtained from related articles and books, newspaper reports and articles, international organizations' reports, and the Bangladesh Fire Service and Civil Defense Authority (BFSCDA) documents. A clear concept regarding Bangladesh's fire crash hazard scenario, necessary books, and relevant laws was consulted and analyzed.

This sample was chosen based on their gender, age, and profession, including police and mobile courts, city corporations, fire service, city planners, academicians, $\mathrm{CBOs}$, and city dwellers. It was found that the more significant part of the respondents is male, but there are a few differences between males $(59.3 \%)$ and females $(40.7 \%)$.

\section{Table 3: Demographic Profile of Respondents $(\mathrm{N}=150)$}

It was also found that the highest of the respondent's maximum (39.3\%) fall into the age group 26-30 and then $32.7 \%$ fall into the age group $21-25$, and 26.7 percent of participants are over the age of 30 , and only $1.3 \%$ of the total respondent's age below 20 (Table 3).

Page 4/13 


\section{Data Analysis}

This research analyzes both primary and secondary data. First, for using the quantitative analysis, all respondent's data from the online questionnaire survey have been inputted in IBM SPSS Statistics 25 and applied to an Ordinal Logistic Regression (OLR) testing to determine the relevance of the urbanization and fire hazards for Dhaka City. Then, all results analysis were classified, tabulated, and presented in the forms of tables and graphs by using the IBM SPSS Statistics 25 and Microsoft 365 Excel. Secondly, The study assisted in conceptualizing the current urbanization structure and institutional framework of fire risk planning in Bangladesh in terms of instrumentation and personnel. Additionally, the data gathered aided in understanding the implications of the actual problem for Dhaka City to achieve the best outcome of the research.

\section{Results \\ Ordinal Logistic Regression (OLR)}

As shown in Table 4, the -2 Log-likelihood chi-square test $\left[x^{2}(11)=72.970, p<.001\right]$ is significant. It is indicated that illegal urbanization has a significant impact on fire crash hazards. Also, we see that the Pearson chi-square test $\left[x^{2}(3164)=2451.478, p=1\right]$ and the Deviance test $\left[x^{2}(3164)=729.285, p=1\right]$ were non-significant. It is shown that fire crash hazards are likely to increase because of illegal urbanization. However, illegal urbanization was a significant $(p<0.05)$ positive predictor over fire crash hazards. It is assumed that a predicted increase of 1.813 in the log odds of being a higher level on fire crash hazards for every one-unit increase in illegal urbanization. In addition, the result from the Test of Parallel lines assumed that it is satisfied because it is also non-significant $(p=1)$. It is also indicated and meant that illegal urbanization is responsible for fire crash hazards.

\section{Discussion}

\section{Assessing the Impacts of Illegal Urbanization on Fire Crash Hazards}

This research assessed Bangladesh's overall rapid unplanned urbanization and the consequences of fir crash hazard in Dhaka city. From the findings and analysis of this study, there is a scenario that can help us realize the endangerment of fire crash hazards resulting from rapid unplanned urbanization. Overall, the outcomes from the Ordinal Logistic Regression (OLR) analysis indicated that it $(p<.001)$ is significant and has impacts on fire crash hazard of Dhaka city. As expected, there are lots of driving factors behind illegal urbanization. It is found that the process of urbanization is rapid and unplanned because of high-rise building construction defects, unauthorized settlements, migrants, corruption, ruling body power, environment pollution, abysmal security, and safety with low life expectancy. Also, it does not obey the laws, and human settlements are not cost-effective.

From the collected analysis of data (Table 5), overall, 141 (94\%) and 137 (91.3\%) respondents strongly or slightly agree that the process of urbanization of Dhaka city is rapid and unplanned because it does not obey the laws and settlements are constructed without following the country's rules and regulations. The mean scores $(\overline{\mathrm{x}}=1.89$ and $\overline{\mathrm{x}}=2.01)$ show the effect with standard deviations 1.148 and 1.256 , respectively. It reveals that the urbanization process will be affected without following and obeying the rules and regulations of urban planning and its laws. Therefore, to some extent, planned or legal urbanization is impossible. Consequently, it may cause a spatial imbalance in urbanization in the future (Islam N., 2018). Also, illegal immigrants of Dhaka city come from different countries. The mean score $(\bar{x}=3.84)$ indicates the substantial effect and causes the illicit urbanization of Dhaka city. Illegal immigrants living in Bangladesh are more than 10 lakh people, especially in Dhaka city from different countries. For example, many people from India (10,227), China (3,652) Nepal (1,518), Pakistan (421), Sri Lanka (534), Russia (348), South Korea (610), North Korea (406), Somalia (122), United States of America (415), and United Kingdom (203) are living Bangladesh and affected the economy and urbanization process of Bangladesh (MANDAL, 2019; Obhijatra, 2019; Mahtab, 2019; Sadeque, 2014).

\section{Table 4: Ordinal Logistic Regression (OLR) Estimation for Fire Crash Hazards in Dhaka City based on Illegal Urbanization by Different Variables.}

The almost same proportion of respondents, 120 (80.1\%) and 121 (80\%), cannot rely on the governing procedure of Dhaka city because the system of governance is thoroughly corrupted, and other people influence the governing body; specifically, politicians. As a result, most of Dhaka's buildings are constructed without following the Rajdhani Unnayan Kartripakkha (Rajuk) rules but using their political powers. A survey was conducted by the Rajuk from January to July 2018, a total of 204,106 buildings in 1528 square kilometers in Dhaka. As a result, about 134,925 buildings, or 66.1 percent, are defective, risky, and uninhabitable (Dhaka Tribune, 2019). In this circumstance, if we measure the urbanization process of Dhaka city by comparing the mean scores, they belong to the potent effect, and the standard deviations are 1.633 and 1.472 , respectively.

Consequently, respondents of this study do not think that human settlements of Dhaka city are cost-effective. Almost all of them indicate that people's security and safety of Dhaka city are abysmal because it is not a sustainable city for living in term of environmental condition that also affects the life expectancy, which is very low in Dhaka city. In the respondent's opinion, it has been evident that the urbanization process in Dhaka city is not a formal and proper urban planning way. Thus, the study's overall results proved that urbanization is in Dhaka city rapid, unplanned, and illegitimate.

On the other hand, illegal urbanization is determined to have an impact on Dhaka's fire crash hazard. A total of 143 (95.3\%) people think fire crash hazards are a regular affair in Dhaka city, and 142 (94.6\%) respondents believe that unplanned urbanization is responsible for fire crash hazards (Table 5). Natural hazards (like earthquakes, floods) and man-made hazards (like fires, sound pollution) frequently occur in Bangladesh. Due to a fire crash hazard that is a regular affair in Dhaka city, people are losing their relatives and monetary losses that make them homeless. In addition, Dhaka city's industrial, residential, and slum areas are experiencing economic loss due to fire incidents (Tishi \& Islam, 2019). A significant portion of respondents (77.3\%) thinks it negatively impacts GDP, GNP, revenue collections, and indirect losses, which cannot be calculated. 
A total of $83.3 \%$ of participants believed that fire crash hazard also affects the infrastructure development of Dhaka city and the country's infrastructure, and it has terrible impacts on the wheel of the entire economy. The mean scores ( $\overline{\mathrm{x}}=2.09$ ) and ( $\overline{\mathrm{x}}=2.01)$ suggest that fire crash strongly affect GDP, GNP, revenue collection, and the infrastructure development of the country.

The study also shows that slum areas of Dhaka city have more significant risks that have unsafe working and living conditions due to rapid and unplanned urbanization. Moreover, fires in Dhaka's slum areas are primarily caused by industrial units due to unauthorized chemical warehouses or factories. Many respondents (89.3\%) think Dhaka's uncontrolled and fast urbanization has brought people into urban slums with potentially dangerous living and working conditions, posing more significant fire risks. Due to slum areas, people are not aware of safety and security. As a result, about $76.7 \%$ of respondents said they do not have clear information about existing rules and regulations against informal urbanization to protect Dhaka. Unfortunately, existing rules and regulations against unplanned urbanization to protect Dhaka city are ambiguous to city dwellers.

As a result, because of a short-staffed investigation department and political interference, the lack of state intervention on all fire units continues to raise the underpinning fire crash hazards. The mean score $(\overline{\mathrm{x}}=2.09)$ reveals that lack of staff and political influences are strongly responsible for the rising fire hazards in Dhaka city. Most importantly, damages of fire crash hazards are increased due to the lack of fire emergency strategies and overcrowding in urban slums. Thus, they $(\overline{\mathrm{x}}=1.83$ and $\sigma=1.122)$ worsen the damages of fire hazards considerably.

In addition, Dhaka City residents' vulnerability to fire crash hazards has risen because of careless housing installation and non-compliance with the Fire Protection Act, 2003. As a result, Dhaka City is now facing a high number of fires. In most cases, a lack of adequate preventative measures, institutional inefficiency, insufficient equipment support, and public awareness exacerbate the problem. In the scenario of Dhaka city, current design regulations and legislation are also inadequate (Islam \& Adri, 2008).

\section{Recommendations And Conclusions}

From the analysis and discussion of study results, it is found that the urbanization of Dhaka city is rapid, unplanned, and illegal due to many factors such as unauthorized settlements, corrupted governance, illegal migration, low life expectancy, expensive settlements, weak construction, feeble life safety and security, and unsustainable due to pollution. Dhaka mega-city is growing uncontrollably, allowing more congestion problems and urban sprawl in the city's center. Because of an absence of excellent governance, Dhaka is presently facing many-sided urban challenges. The rapid expansion of a majestic and illegal urban development procedure in Dhaka affects the urbanities' livelihoods. Furthermore, climate hazards amplify the severity of the problems, feat voters with associate degree indefinable future. A Dhaka city is overwhelmingly growing because of pull and push factors, while service provisions and income-earning opportunities are not provided simultaneously. Thus, the city gradually suffers from inadequate infrastructural services, social insecurity, natural and artificial hazards. The result of this research also reveals that this illegal urbanization process of Dhaka city has an impact on fire crash hazard which cost lives, damage infrastructure development and economic, worse the living and working conditions and rise high risks, especially industrial and overpopulated slum areas. Extensive intervention is highly needed to recognize the appearance of territory and allocate or control operation in a systematic way (Pelling \& Blackburn, 2013). Based on the collected data and analysis, the following recommendations are proposed to protect from illegal urbanization and reduce fire crash hazards in Dhaka city and Bangladesh.

1. Proper social control of black eye rules and much ought to be ensured in building construction. Moreover, the system of governance should be entirely lawful.

2. Ensure strict enforcement and proper monitoring of the existing legal provisions.

3. Bangladesh Fire Service Ordinance and laws relating to urbanization should be publicized and appropriately enforced. Warehouses and workshops must be included in the ordinance should be strictly enforced and segregated from residential areas.

4. There must be set up appropriately land-use zoning for industrial and residential areas. For example, the residential areas should not get permission for industrial activity and warehouses. Also, garments industries should be shifted from residential areas to industrial zones.

5. For ensuring better and more effective services, it is necessary to increase the number of fire stations within Dhaka City. Therefore, of course, the stations should be constructed on a priority basis.

6. The modern training program should be provided for the Bangladesh Fire Service and Civil Defense Authority (BFSCDA). Most importantly, for effective management of firefighting, there should be appointed experienced consultants.

7. In the rapid urbanization and unplanned areas, the government should take necessary steps to widen the road. Also, there should be proper plans for high-rise buildings.

8. For making people aware of fire hazards, electronic media and newspapers could be helpful to the source. Also, mandatory training should be arranged for staff working in various residential and commercial buildings in highly hazardous areas.

9. Fire safety measures, such as automatic sprinklers, warning systems, smoke detectors, fire extinguishers, and hydrants, should be readily available in high-risk fire crash areas. Most importantly, modern firefighting equipment such as pumps, ambulances, and fire vehicles.

\section{Declarations}

Conflict of Interest: The authors declare that they have no conflict of interest.

Funding: No funds, grants, or other support was received. 
Ethical approval: "All procedures performed in studies involving human participants were in accordance with the ethical standards of the institutional and/or national research committee and with the 1964 Helsinki declaration and its later amendments or comparable ethical standards."

"This research does not contain any studies with animals performed by any of the authors."

Informed consent: "Informed consent was obtained from all individual participants included in the study."

\section{References}

BBS. (2014). Population and Housing Census. Dhaka, Bangladesh: Bangladesh Bureau of Statistics.

BFSCDA. (2019, August 20). Yearly Data. Fire Incident Data. Retrieved from Bangladesh Fire Service and Civil Defence. Government of the People's Republic of Bangladesh: www.fireservice.gov.bd/site/page/18e08e09-ad74-4aa6-9494-84d1fdc18ad3/Fire-Incident

BFSCDA. (2020, September 13). Yearly Data. Fire Incident Data. Retrieved from Bangladesh Fire Service and Civil Defence. Government of the People's Republic of Bangladesh:

http://www.fireservice.gov.bd/sites/default/files/files/fireservice.portal.gov.bd/files/eb166e23_27b4_41c8_8176_39cc63063f71/2021-02-15-13-51-

19fe4ac324dbae46ba9985fa2086e90f.pdf

CBSNews. (2010). Bangladesh Fire Rips through Building, 116 Dead. New York: CBS News.

Daniels, P. (2004). Urban challenges: The formal and informal economies in mega-cities. Cities , 21, 501-511.

David, B., \& Kristen, G. (2021). Fire Hazard Analysis: Quantifying and Mitigating Design Basis Fire Events. San Antonio: BakerRisk. Retrieved December 12, 2021, from https://www.bakerrisk.com/wp-content/uploads/BakerRisk_Best_Practices-FHMA-FNL_WebRes_Spreads.pdf

Dhaka Tribune. (2019). 16,000 fire incidents in 10 years. Dhaka: DhakaTribune.

Dhaka Tribune. (2019). Two thirds of Dhaka buildings illegal. Dhaka: Dhaka Tribune. Retrieved October 14, 2021, from

https://www.dhakatribune.com/bangladesh/dhaka/2019/02/03/two-thirds-of-dhaka-buildings-illegal

DIPECHO. (2010). Urban Risk Assessment. Brussels: Disaster Preparedness European Commission's Humanitarian Aid Department.

Hackenbroch, K., Hossain, S., Altrock, U., Schoon, S., \& Sterly, H. (2016). Informality, urban governance and the state: Negotiations of space in Dhaka and the Pearl River Delta . Int. Dev. Plan. Rev., 38, 229-253.

Hossain, S. (2012). The production of space in the negotiation of water and electricity supply in a bosti of Dhaka. Habitat Int. , 36, 68-77.

Huq, S. (1999). Environmental hazards in Dhaka. In: Mitchell, J.K. (ed) Crucibles of Hazard: Mega-Cities and Disasters in Transition. Tokyo, Japan: United Nations University Press.

Hutchison, R. (2010). (Ed.). Encyclopedia of Urban Studies. . Thousand Oaks, CA: SAGE Publications, Inc.

Imam, H. (2010). Nimtoli tragedy: The worst nightmare. Dhaka, Bangladesh: The Daily Star.

Islam, M. M., \& Adri, N. (2008). Fire Hazard Management of Dhaka City: Addressing Issues Relating to Institutional Capacity and Public Perception. Jahangirnagar Planning Review, 6, 57-67.

Islam, N. (2018). Urbanisation in Bangladesh: Recent Trends and Challenges. Dhaka: Daily Sun. Retrieved from https://www.dailysun.com/post/345303/Urbanisation-in-Bangladesh:-Recent-Trends-and-Challenges

Mahtab, F. U. (2019). What is the number of illegal immigrants? (Bengali). Dhaka: Samakal. Retrieved October 14, 2021, from https://samakal.com/bangladesh/article/1909502/\%E0\%A6\%AC\%E0\%A6\%BF\%E0\%A6\%A6\%E0\%A7\%87\%E0\%A6\%B6\%E0\%A6\%BF\%E0\%A6\%B0\%E0\%A6\%B8\%E0\%A6\%82\%E0\%A6\%96\%E0\%A7\%8D\%E0\%A6\%AF\%E0\%A6\%BE-\%E0\%A6\%95\%E0\%A6\%A4

MANDAL, D. (2019). What Bangladeshi media is saying about illegal immigrants from India: The number of illegal immigrants, of which 5 lakh are reportedly Biharis, in Bangladesh is swelling. New Delhi: The Print. Retrieved October 14, 2021, from https://theprint.in/opinion/what-bangladeshi-media-issaying-about-illegal-immigrants-from-india/308045/\#google_vignette

Maniruzzaman K.M., H. Q. (2013). Fire Hazard in Dhaka City: A Case Study of the Service Area of Mohammadpur Fire Station. Dhaka: Bangladesh Institute of Planners. Retrieved from Bangladesh Institute of Planners.

Montgomery, M. R., Stren, R., Cohen, B., \& Reed, H. E. (2003). Cities transformed: Demographic Change and Its Implications in the Developing World (1 st ed.). London: Routledge. doi:https://doi.org/10.4324/9781315065700

Nikolai, B., Marty, A., Sergei, S., \& Peter, W. (2017). World fire statistics, International Association of Fire and Rescue Services, No. 22. Center of Fire Statistics. Retrieved 5 2021, December, from https://www.ctif.org/sites/default/files/ctif_report22_world_fire_statistics_2017.pdf

Page $7 / 13$ 
Notridge, H. E. (2007). The Sociology of Urban Living. London: Routledge and Kegan Paul.

Obhijatra. (2019). Illegal foreigners are increasing the pressure on the country's economy (Bengali). Dhaka: Obhijatra. Retrieved October 14, 2021, from https://obhijatra.com/news/\%e0\%a6\%9c\%e0\%a6\%be\%e0\%a6\%a4\%e0\%a7\%80\%e0\%a7\%9f/\%e0\%a6\%a6\%e0\%a7\%87\%e0\%a6\%b6\%e0\%a7\%87\%e0\%a6\%b0\%e0\%a6\%85\%e0\%a6\%b0\%e0\%a7\%8d\%e0\%a6\%a5\%e0\%a6\%a8\%e0\%a7\%80\%e0\%a6\%a4\%e0\%a6\%bf\%e0\%a6\%a4\%e0\%a7\%87-

\%e0\%a6\%9a\%e0\%a6\%be\%e0\%a6\%aa-\%e0\%a6\%ac\%e0\%a6\%b

Pelling, M., \& Blackburn, S. (. (2013). Executive Summary. In Mega-cities and the Coast: Risk, Resilience and Transformation. New York, USA,: Routledge.

RAJUK. (2015). Dhaka Structure Plan 2016-2035. Dhaka, Bangladesh: Rajdhani Unnayan Kartripakkha.

Sadeque, S. S. (2014). Dhaka has a question: what about the illegal Indian immigrants in Bangladesh? The Bangladeshi government estimates there are 500,000 Indians working in the country. Scroll.in. Retrieved October 14, 2021, from https://scroll.in/article/664305/dhaka-has-a-question-what-about-theillegal-indian-immigrants-in-bangladesh

Swapan, M. S., \& U., A. (2017). Transforming Urban Dichotomies and Challenges of South Asian Mega-cities: Rethinking Sustainable Growth of Dhaka, Bangladesh. Urban Sci., 1, 31.

Tanjiba Rahman, T., \& Ishrat, I. (2019). Urban fire occurrences in the Dhaka Metropolitan Area. GeoJournal(84), $1417-1427$.

doi:https://doi.org/10.1007/s10708-018-9923-y

The Geneva Association. (2014). World Fire Statistics Bulletin No. 29. Geneva: World Fire Statistics Centre. Retrieved December 5, 2021, from https://www.genevaassociation.org/research-topics/world-fire-statistics-bulletin-no-29

Tishi, T. R., \& Islam, I. (2019). Urban fire occurrences in the Dhaka Metropolitan Area. GeoJournal(84), 1417-1427. doi:https://doi.org/10.1007/s10708-0189923-y

U.S. Geological Survey. (n.d.). Earthquake Hazards Program. Retrieved December 12, 2021, from Casualties and damage after the 1906 Earthquake: https://earthquake.usgs.gov/earthquakes/events/1906calif/18april/casualties.php

United Nations, Department of Economic and Social Affairs, Population Division. (2019). World Urbanization Prospects: The 2018 Revision (ST/ESA/SER.A/420). New York: United Nations. Retrieved from https://population.un.org/wup/Publications/Files/WUP2018-Report.pdf

Venkatesh, K., Puneet, K., \& Muhammad Masood, R. (2020). Fire hazard in buildings: review, assessment and strategies for improving fire safety. PSU Research Review, 4(1), 1-23. doi:10.1108/PRR-12-2018-0033

Watch, H. R. (2013, April 25). Bangladesh: Tragedy Shows Urgency of Worker Protections: Allow Workers to Unionize; Overhaul Factory Inspections. Retrieved from Human Rights Watch: https://www.hrw.org/news/2013/04/25/bangladesh-tragedy-shows-urgency-worker-protections

Westfall, M. S., \& Villa, V. A. (2001). Urban Indicators for Managing Cities. Asian Development Bank. Retrieved from http://hdl.handle.net/11540/276

World Bank. (2015). Leveraging Urbanization in South Asia: Managing Spatial Transformation for Prosperity and Livability (Leveraging Urbanization in Bangladesh). Washington, DC: The World Bank Group. Retrieved from https://www.worldbank.org/en/country/bangladesh/brief/leveraging-urbanizationbangladesh

\section{Tables}


Different Definitions of Urbanization by Chosen Countries.

\begin{tabular}{|c|c|}
\hline $\begin{array}{l}\text { Name of } \\
\text { Country }\end{array}$ & Various Definitions of Urbanization \\
\hline Argentina & Places with a population of $\geq 2,000$ people. \\
\hline Australia & Before 2001 , urban centers with $\geq 1,000$ inhabitants, and for 2001 and later, with $\geq 10,000$ inhabitants. \\
\hline Belgium & Communes with $\geq 5,000$ inhabitants. \\
\hline Canada & $\begin{array}{l}\text { Till 1981, spaces with } \geq 1,000 \text { residents and the population density with a minimum of } 400 \text { persons per square kilometer. Between } 1951 \\
\text { and } 1981 \text {, the term urban modified a little. }\end{array}$ \\
\hline China & $\begin{array}{l}\text { The urban population can be described as all those residing in urban territories with a minimum of } 1500 \text { persons per square kilometer } \\
\text { since the } 2000 \text { census. Also, the urbanization for the } 2010 \text { national survey included only those city residents who reached the standard set } \\
\text { by China's National Bureau of Statistics in } 2008 \text {. (e.g., the requirement was included in the } 2000 \text { survey, and citizens residing in rural areas } \\
\text { or small cities outside towns and suburbs closely linked to local government services and getting government facilities from urban } \\
\text { municipal governments were considered). }\end{array}$ \\
\hline France & $\begin{array}{l}\text { According to the definition of the urban area, inhabitants with } 2,000 \text { or perhaps more dwellers in residences kept their distance by no more } \\
\text { than } 200 \text { meters. }\end{array}$ \\
\hline Germany & Locales have a population size of minimal 150 persons for every square kilometer. \\
\hline India & $\begin{array}{l}\text { Locations are with a municipal government, corporate entity, military barracks board, or notified town area committee, as well as other } \\
\text { areas that meet all the requirements listed below: (1) 5,000 or more people; (2) minimal } 75 \% \text { of the male workforce engaged in non- } \\
\text { agricultural activities; and (3) minimum } 400 \text { individuals per square kilometer. }\end{array}$ \\
\hline Japan & $\begin{array}{l}\text { Cities (shi) are municipalities that meet the mentioned conditions: (1) } 50,000 \text { or more residents; (2) over } 60 \% \text { of the residences are situated } \\
\text { in the significant established zones; and (3) more than } 60 \% \text { of the inhabitants (including their household members) is involved in the } \\
\text { production, commerce, or any other urban economic activities. }\end{array}$ \\
\hline $\begin{array}{l}\text { New } \\
\text { Zealand }\end{array}$ & 1,000 or even more citizens in urban areas, boroughs, city districts, towns and villages, and country areas. \\
\hline $\begin{array}{l}\text { Saudi } \\
\text { Arabia }\end{array}$ & Cities are with 5,000 inhabitants or more. \\
\hline Turkey & Localities are situated inside the administrative boundaries of districts and provinces. \\
\hline $\begin{array}{l}\text { United } \\
\text { Kingdom }\end{array}$ & Settlements have some individuals of 10,000 or more folks. Before 1971 , administrative boundary lines were shown. \\
\hline $\begin{array}{l}\text { United } \\
\text { States of } \\
\text { America }\end{array}$ & $\begin{array}{l}\text { With } 2,500 \text { or even more residents, the highly populated land satisfies minimal urban population criteria. However, the concept for the } \\
2000 \text { census was adjusted to density-based from place-based. Therefore, before and after this time, it impacts the estimation of } \\
\text { comparisons. }\end{array}$ \\
\hline Zimbabwe & $\begin{array}{l}\text { Regions are formally recognized as urban areas with } 2,500 \text { or more settlers and a tight housing sequence. Non-agricultural occupations } \\
\text { employ more than half of the working population. }\end{array}$ \\
\hline
\end{tabular}

Table 2

Estimation of Fire Crash Hazards in Dhaka City.

\begin{tabular}{|lll|}
\hline Year(s) & Number of Fire Crash Hazard(s) & Estimated loss Amount (TK) \\
\hline 2014 & 5392 & $1,780,286,190.00 \rrbracket$ \\
\hline 2015 & 5,752 & $6,702,014,887.00 \rrbracket$ \\
\hline 2016 & 5,595 & $1,294,293,612.00 \rrbracket$ \\
\hline 2017 & 5,066 & $919,676,622.00 \rrbracket$ \\
\hline 2018 & 6,208 & $1,668,632,410.00 \rrbracket$ \\
\hline Source: Author's calculation based on the collected information from the Bangladesh Fire Service and Civil Defense Authority (BFSCDA, 2019). \\
\hline
\end{tabular}


Table 3

Demographic Profile of Respondents ( $N=150)$

\begin{tabular}{|llll|}
\hline Demographic Profile & Range / Variables & Frequency & Percentage (\%) \\
\hline Gender & Female & 61 & 40.7 \\
\cline { 2 - 3 } & Male & 89 & 59.3 \\
\hline Total & 20 and Below & 150 & 100.0 \\
\hline $21-25$ & 2 & 1.3 \\
\hline $26-30$ & 49 & 32.7 \\
\hline 31 and Above & 59 & 39.3 \\
\hline Total & 40 & 26.7 \\
\hline Academicians & 150 & 100.0 \\
\hline City Planners & 30 & 20.0 \\
\hline Businessmen & 11 & 7.3 \\
\hline CBOs/NGOs Workers & 10 & 6.7 \\
\hline City Corporation (Officers/Workers) & 9 & 13.3 \\
\hline Police and Fire Service (Officers/Staffs) & 15 & 6.0 \\
\hline City Dwellers/ People/Students/Others & 55 & 10.0 \\
\hline Total & 150 & 100.0 \\
\hline & 20 & \\
\hline
\end{tabular}


Table 4

Ordinal Logistic Regression (OLR) Estimation for Fire Crash Hazards in Dhaka City based on Illegal Urbanization by Different Variables.

\begin{tabular}{|c|c|c|c|c|c|}
\hline Independent/Dependent Variables & & Est. Coef. & Std. Error & $P(*)$ & $\mathbf{N}$ \\
\hline \multirow[t]{25}{*}{ Fire Crash Hazard Variables } & $\mathrm{V}-1$ & 1.487 & .797 & .062 & 11 \\
\hline & $\mathrm{V}-2$ & 2.281 & .780 & .003 & 10 \\
\hline & V-3 & 2.562 & .778 & .001 & 5 \\
\hline & V-4 & 3.038 & .779 & .000 & 10 \\
\hline & V-5 & 3.290 & .781 & .000 & 6 \\
\hline & V-6 & 3.677 & .785 & .000 & 10 \\
\hline & $\mathrm{V}-7$ & 4.001 & .790 & .000 & 9 \\
\hline & V-8 & 4.510 & .801 & .000 & 15 \\
\hline & V-9 & 5.104 & .816 & .000 & 17 \\
\hline & V-10 & 5.708 & .835 & .000 & 15 \\
\hline & V-11 & 6.135 & .852 & .000 & 9 \\
\hline & V-12 & 6.291 & .859 & .000 & 3 \\
\hline & V-13 & 6.582 & .874 & .000 & 5 \\
\hline & V-14 & 7.083 & .904 & .000 & 7 \\
\hline & V-15 & 7.451 & .930 & .000 & 4 \\
\hline & V-16 & 7.559 & .939 & .000 & 1 \\
\hline & V-17 & 7.807 & .960 & .000 & 2 \\
\hline & V-18 & 7.955 & .974 & .000 & 1 \\
\hline & V-19 & 8.308 & 1.011 & .000 & 2 \\
\hline & V-20 & 8.526 & 1.037 & .000 & 1 \\
\hline & V-21 & 9.169 & 1.134 & .000 & 2 \\
\hline & V-22 & 9.693 & 1.238 & .000 & 1 \\
\hline & $V-23$ & 10.608 & 1.455 & .000 & 1 \\
\hline & V-24 & 11.720 & 1.689 & .000 & 1 \\
\hline & $V-25$ & 12.957 & 1.934 & .000 & 1 \\
\hline \multicolumn{2}{|l|}{ Illegal Urbanization } & 1.813 & .246 & .000 & $N=150$ \\
\hline \multicolumn{6}{|c|}{ 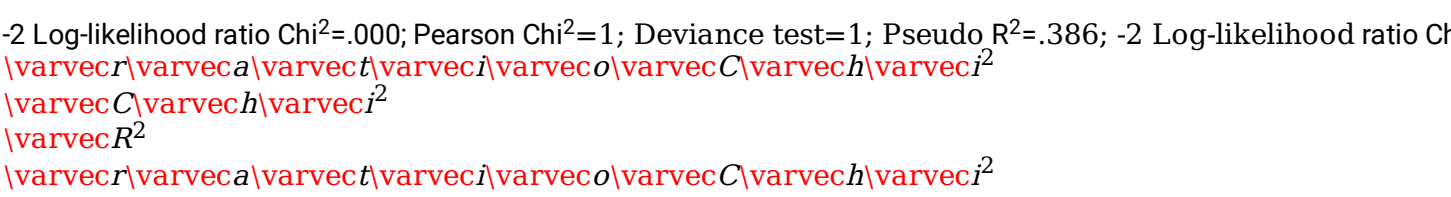 } \\
\hline
\end{tabular}

Table 5: Respondents' Assessment of the Impacts of Illegal Urbanization on Fire Crash Hazard. 


\begin{tabular}{|c|c|c|c|c|c|c|c|c|c|c|c|}
\hline \multirow{2}{*}{$\begin{array}{l}\text { Respondent Category: Members of } \\
\text { Police and Mobile Courts, City } \\
\text { Corporations, Fire Service, City } \\
\text { Planners, Academicians, CBOs, and } \\
\text { City Dwellers. }\end{array}$} & \multicolumn{7}{|c|}{ Assessment level of Impacts } & \multirow{3}{*}{$\begin{array}{c}\text { Total } \\
\mathrm{N}=150\end{array}$} & \multirow{3}{*}{$\begin{array}{c}\text { Mean } \\
\text { Score } \\
(\overline{\mathrm{x}})\end{array}$} & \multirow{3}{*}{$\begin{array}{l}\text { Std. } \\
\text { Deviation } \\
(\sigma)\end{array}$} & \multirow{3}{*}{$\begin{array}{l}\text { Std. } \\
\text { Error } \\
(\mathrm{SE})\end{array}$} \\
\hline & \multirow[t]{2}{*}{$\begin{array}{l}\text { Strongly } \\
\text { Agree }\end{array}$} & \multirow[t]{2}{*}{ Agree } & \multirow[t]{2}{*}{$\begin{array}{l}\text { Somewhat } \\
\text { Agree }\end{array}$} & \multirow[t]{2}{*}{$\begin{array}{l}\text { Neither } \\
\text { Agree } \\
\text { nor } \\
\text { Disagree }\end{array}$} & \multirow[t]{2}{*}{$\begin{array}{l}\text { Somewhat } \\
\text { Disagree }\end{array}$} & \multirow[t]{2}{*}{ Disagree } & \multirow[t]{2}{*}{$\begin{array}{l}\text { Strongly } \\
\text { Disagree }\end{array}$} & & & & \\
\hline Illegal Urbanization Indicators & & & & & & & & & & & \\
\hline $\begin{array}{l}\text { Unauthorized process of } \\
\text { urbanization }\end{array}$ & $\begin{array}{l}64 \\
(42.7) \\
\end{array}$ & $\begin{array}{l}59 \\
(39.3)\end{array}$ & $\begin{array}{l}18 \\
(12.0)\end{array}$ & $\begin{array}{l}4 \\
(2.7) \\
\end{array}$ & $\begin{array}{l}1 \\
(0.7)\end{array}$ & $\begin{array}{l}1 \\
(0.7)\end{array}$ & $\begin{array}{l}3 \\
(2.0)\end{array}$ & 150 & 1.89 & 1.148 & .094 \\
\hline Illlegal settlements & $\begin{array}{l}59 \\
(39.3)\end{array}$ & $\begin{array}{l}61 \\
(40.7)\end{array}$ & $\begin{array}{l}17 \\
(11.3)\end{array}$ & $\begin{array}{l}4 \\
(2.7)\end{array}$ & $\begin{array}{l}4 \\
(2.7)\end{array}$ & $\begin{array}{l}2 \\
(1.3)\end{array}$ & $\begin{array}{l}3 \\
(2.0)\end{array}$ & 150 & 2.01 & 1.256 & .103 \\
\hline Bad governance & $\begin{array}{l}49 \\
(32.7)\end{array}$ & $\begin{array}{l}43 \\
(28.7)\end{array}$ & $\begin{array}{l}28 \\
(18.7)\end{array}$ & $\begin{array}{l}13 \\
(8.7)\end{array}$ & $\begin{array}{l}4 \\
(2.7)\end{array}$ & $\begin{array}{l}6 \\
(4.0)\end{array}$ & $\begin{array}{l}7 \\
(4.7)\end{array}$ & 150 & 2.51 & 1.633 & .133 \\
\hline Illegal migrants & $\begin{array}{l}12 \\
(8.0) \\
\end{array}$ & $\begin{array}{l}22 \\
(14.7)\end{array}$ & $\begin{array}{l}33 \\
(22.0)\end{array}$ & $\begin{array}{l}31 \\
(20.7)\end{array}$ & $\begin{array}{l}21 \\
(14.0) \\
\end{array}$ & $\begin{array}{l}25 \\
(16.7)\end{array}$ & $\begin{array}{ll}6 \\
(4.0)\end{array}$ & 150 & 3.84 & 1.639 & .134 \\
\hline Others influence & $\begin{array}{l}47 \\
(31.3)\end{array}$ & $\begin{array}{l}56 \\
(37.3)\end{array}$ & $\begin{array}{l}18 \\
(12.0)\end{array}$ & $\begin{array}{l}15 \\
(10.0)\end{array}$ & $\begin{array}{l}6 \\
(4.0)\end{array}$ & $\begin{array}{l}4 \\
(2.7)\end{array}$ & $\begin{array}{l}4 \\
(2.7)\end{array}$ & 150 & 2.37 & 1.472 & .120 \\
\hline High life expectancy & $\begin{array}{l}13 \\
(8.7)\end{array}$ & $\begin{array}{l}50 \\
(33.3)\end{array}$ & $\begin{array}{l}41 \\
(27.3)\end{array}$ & $\begin{array}{l}15 \\
(10.0)\end{array}$ & $\begin{array}{l}7 \\
(4.7)\end{array}$ & $\begin{array}{l}17 \\
(11.3)\end{array}$ & $\begin{array}{l}7 \\
(4.7)\end{array}$ & 150 & 3.21 & 1.645 & .134 \\
\hline $\begin{array}{ll}\text { Cost-effective } & \text { human } \\
\text { settlements } & \end{array}$ & $\begin{array}{l}27 \\
(18.0)\end{array}$ & $\begin{array}{l}30 \\
(20.0)\end{array}$ & $\begin{array}{l}13 \\
(8.7)\end{array}$ & $\begin{array}{l}6 \\
(4.0)\end{array}$ & $\begin{array}{l}9 \\
(6.0)\end{array}$ & $\begin{array}{l}28 \\
(18.7)\end{array}$ & $\begin{array}{l}37 \\
(24.7)\end{array}$ & 150 & 4.15 & 2.356 & .192 \\
\hline Regular natural hazards & $\begin{array}{l}74 \\
(49.3)\end{array}$ & $\begin{array}{l}52 \\
(34.7)\end{array}$ & $\begin{array}{l}8 \\
(5.3)\end{array}$ & $\begin{array}{l}5 \\
(3.3)\end{array}$ & $\begin{array}{ll}2 \\
(1.3)\end{array}$ & $\begin{array}{l}4 \\
(2.7)\end{array}$ & $\begin{array}{l}5 \\
(3.3)\end{array}$ & 150 & 1.94 & 1.439 & .117 \\
\hline Unplanned high-rise buildings & $\begin{array}{l}91 \\
(60.7) \\
\end{array}$ & $\begin{array}{l}44 \\
(29.3) \\
\end{array}$ & $\begin{array}{l}7 \\
(4.7) \\
\end{array}$ & $\begin{array}{ll}3 \\
(2.0) \\
\end{array}$ & $\begin{array}{l}0 \\
(0) \\
\end{array}$ & $\begin{array}{ll}1 \\
(0.7) \\
\end{array}$ & $\begin{array}{ll}4 \\
(2.7) \\
\end{array}$ & 150 & 1.64 & 1.177 & .096 \\
\hline Environment-friendly city & $\begin{array}{l}9 \\
(6.0)\end{array}$ & $\begin{array}{l}8 \\
(5.3)\end{array}$ & $\begin{array}{l}10 \\
(6.7)\end{array}$ & $\begin{array}{l}15 \\
(10.0)\end{array}$ & $\begin{array}{l}21 \\
(14.0)\end{array}$ & $\begin{array}{l}42 \\
(28.0)\end{array}$ & $\begin{array}{l}45 \\
(30.0)\end{array}$ & 150 & 5.25 & 1.802 & .147 \\
\hline Weak security and safety & $\begin{array}{l}76 \\
(50.7)\end{array}$ & $\begin{array}{l}60 \\
(40.0)\end{array}$ & $\begin{array}{l}3 \\
(2.0)\end{array}$ & $\begin{array}{l}5 \\
(3.3)\end{array}$ & $\begin{array}{l}1 \\
(0.7)\end{array}$ & $\begin{array}{l}2 \\
(1.3)\end{array}$ & $\begin{array}{l}3 \\
(2.0)\end{array}$ & 150 & 1.75 & 1.175 & .096 \\
\hline \multicolumn{12}{|l|}{ Fire Crash Hazard Indicators } \\
\hline Regular affairs & $\begin{array}{l}74 \\
(49.3)\end{array}$ & $\begin{array}{l}56 \\
(37.3)\end{array}$ & $\begin{array}{l}13 \\
(8.7)\end{array}$ & $\begin{array}{l}3 \\
(2.0) \\
\end{array}$ & $\begin{array}{l}2 \\
(1.3)\end{array}$ & $\begin{array}{l}1 \\
(0.7)\end{array}$ & $\begin{array}{l}1 \\
(0.7)\end{array}$ & 150 & 1.73 & .994 & .081 \\
\hline $\begin{array}{l}\text { Effect on the country's } \\
\text { economic development }\end{array}$ & $\begin{array}{l}53 \\
(35.3) \\
\end{array}$ & $\begin{array}{l}77 \\
(51.3) \\
\end{array}$ & $\begin{array}{l}11 \\
(7.3)\end{array}$ & $\begin{array}{ll}6 \\
(4.0)\end{array}$ & $\begin{array}{l}0 \\
(0)\end{array}$ & $\begin{array}{l}1 \\
(0.7)\end{array}$ & $\begin{array}{ll}2 \\
(1.3)\end{array}$ & 150 & 1.89 & 1.011 & .083 \\
\hline $\begin{array}{lcl}\text { Affect the infrastructure } \\
\text { development }\end{array}$ & $\begin{array}{l}50 \\
(33.3) \\
\end{array}$ & $\begin{array}{l}75 \\
(50.0) \\
\end{array}$ & $\begin{array}{ll}13 \\
(8.7) \\
\end{array}$ & $\begin{array}{ll}4 \\
(2.7) \\
\end{array}$ & $\begin{array}{ll}3 \\
(2.0)\end{array}$ & $\begin{array}{ll}3 \\
(2.0) \\
\end{array}$ & $\begin{array}{ll}2 \\
(1.3) \\
\end{array}$ & 150 & 2.01 & 1.170 & .096 \\
\hline $\begin{array}{l}\text { Effects on GDP, GNP, and } \\
\text { revenue. }\end{array}$ & $\begin{array}{l}44 \\
(29.3) \\
\end{array}$ & $\begin{array}{l}72 \\
(48.0) \\
\end{array}$ & $\begin{array}{l}24 \\
(16.0) \\
\end{array}$ & $\begin{array}{ll}4 \\
(2.7) \\
\end{array}$ & $\begin{array}{ll}3 \\
(2.0) \\
\end{array}$ & $\begin{array}{ll}3 \\
(2.0) \\
\end{array}$ & $\begin{array}{ll}2 \\
(1.3) \\
\end{array}$ & 150 & 2.09 & 1.155 & .094 \\
\hline $\begin{array}{l}\text { Hazardous living and working } \\
\text { conditions }\end{array}$ & $\begin{array}{l}78 \\
(52.0) \\
\end{array}$ & $\begin{array}{l}52 \\
(34.7) \\
\end{array}$ & $\begin{array}{l}10 \\
(6.7) \\
\end{array}$ & $\begin{array}{ll}5 \\
(3.3) \\
\end{array}$ & $\begin{array}{l}1 \\
(0.7) \\
\end{array}$ & $\begin{array}{l}1 \\
(0.7) \\
\end{array}$ & $\begin{array}{ll}3 \\
(2.0) \\
\end{array}$ & 150 & 1.76 & 1.157 & .094 \\
\hline $\begin{array}{l}\text { Unauthorized chemical } \\
\text { warehouses or factories }\end{array}$ & $\begin{array}{l}78 \\
(52.0) \\
\end{array}$ & $\begin{array}{l}52 \\
(34.7) \\
\end{array}$ & $\begin{array}{l}10 \\
(6.7)\end{array}$ & $\begin{array}{l}7 \\
(4.7) \\
\end{array}$ & $\begin{array}{l}1 \\
(0.7)\end{array}$ & $\begin{array}{l}0 \\
(0) \\
\end{array}$ & $\begin{array}{ll}2 \\
(1.3) \\
\end{array}$ & 150 & 1.73 & 1.048 & .086 \\
\hline Vague rules and regulations & $\begin{array}{l}37 \\
(24.7) \\
\end{array}$ & $\begin{array}{l}78 \\
(52.0) \\
\end{array}$ & $\begin{array}{l}20 \\
(13.3) \\
\end{array}$ & $\begin{array}{l}9 \\
(6.0) \\
\end{array}$ & $\begin{array}{l}3 \\
(2.0)\end{array}$ & $\begin{array}{l}2 \\
(1.3)\end{array}$ & $\begin{array}{l}1 \\
(0.7)\end{array}$ & 150 & 2.15 & 1.079 & .088 \\
\hline $\begin{array}{l}\text { Lack of state intervention and } \\
\text { politics }\end{array}$ & $\begin{array}{l}42 \\
(28.0)\end{array}$ & $\begin{array}{l}75 \\
(50.0) \\
\end{array}$ & $\begin{array}{l}22 \\
(14.7)\end{array}$ & $\begin{array}{l}5 \\
(3.3) \\
\end{array}$ & $\begin{array}{l}2 \\
(1.3)\end{array}$ & $\begin{array}{l}2 \\
(1.3) \\
\end{array}$ & $\begin{array}{l}2 \\
(1.3) \\
\end{array}$ & 150 & 2.09 & 1.107 & .090 \\
\hline $\begin{array}{l}\text { Lack of fire evacuation methods } \\
\text { and overpopulation in urban } \\
\text { slums }\end{array}$ & $\begin{array}{l}63 \\
(42.0)\end{array}$ & $\begin{array}{l}71 \\
(47.3)\end{array}$ & $\begin{array}{l}8 \\
(5.3)\end{array}$ & $\begin{array}{l}3 \\
(2.0)\end{array}$ & $\begin{array}{l}1 \\
(0.7)\end{array}$ & $\begin{array}{l}0 \\
(0)\end{array}$ & $\begin{array}{l}4 \\
(2.7)\end{array}$ & 150 & 1.83 & 1.122 & .092 \\
\hline
\end{tabular}

Note: The mean ( $\overline{\mathrm{x}}$ ) score 6.00-2.01 suggests strong effect; 2.00-1.01 suggests- moderate effect; 1.00-0.01 suggests- weak effect; and score 0-0 indicates-insignificant effect.

Figures 


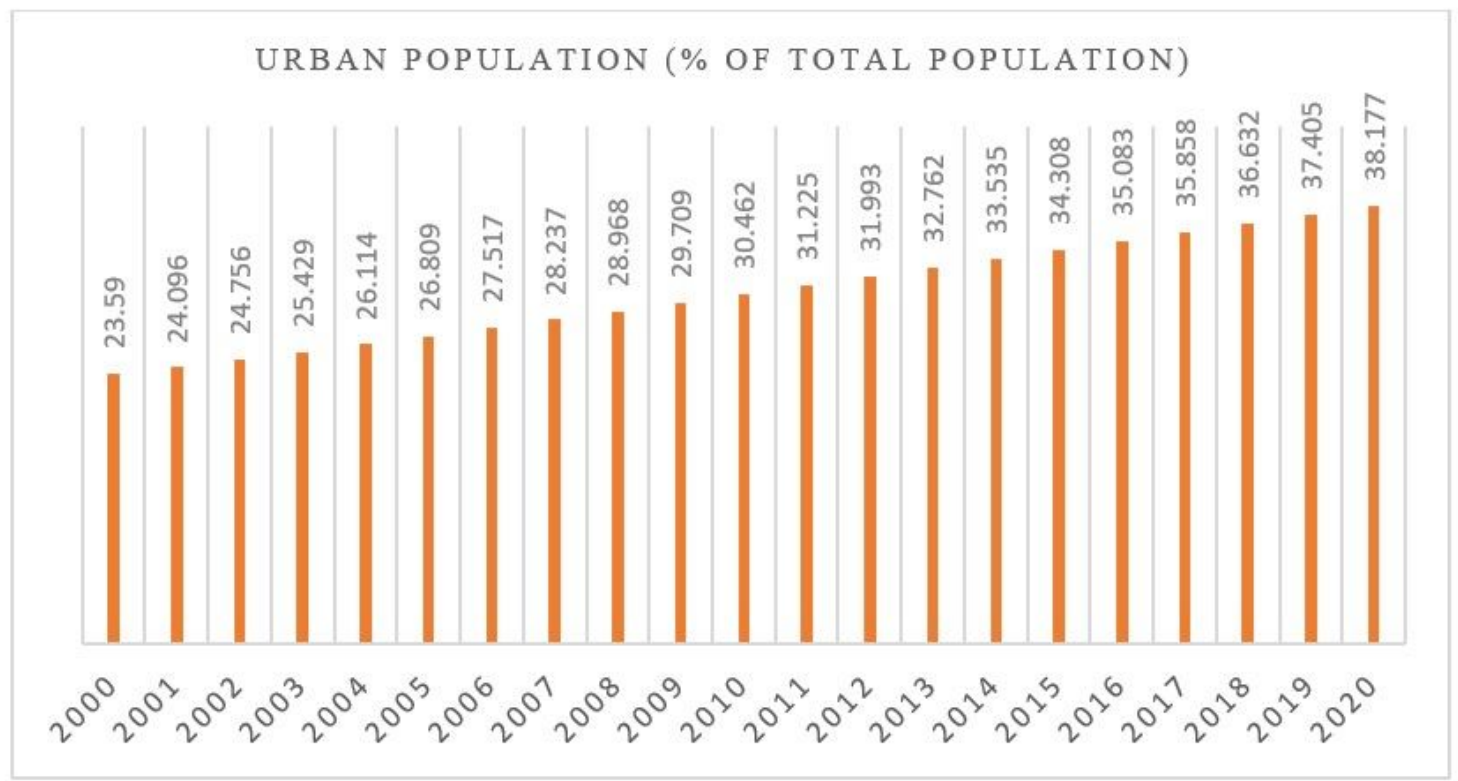

Figure 1

The Growth of Urban Population in Bangladesh.

Source: United Nations Population Division. World Urbanization Prospects: 2018 Revision.

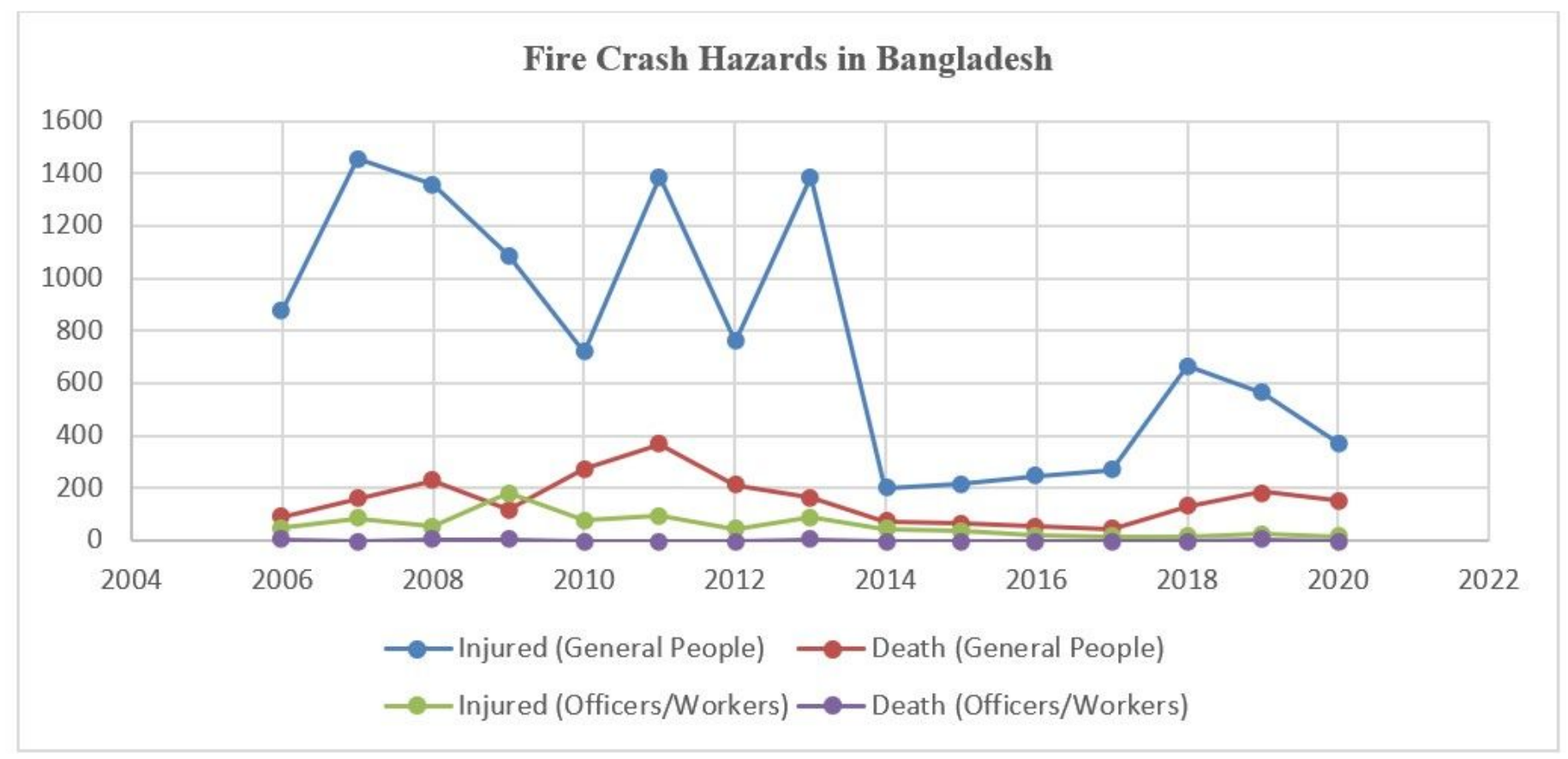

Figure 2

Deaths and Injured People due to the Fire Crash Hazards in Bangladesh (2006-2020).

Source: Author's calculation based on the Bangladesh Fire Service and Civil Defense Authority (BFSCDA, 2019; BFSCDA, 2020). 